KeMAS 16 (2) (2020) 256-262
Jirnal Kesehatan Masyarakat

\title{
Performance of Papua Petanque Athletes Facing Covid-19
}

\author{
Kurdi $^{1 凶}$, Rif’iy Qomarrullah, I Putu Eka Wijaya Putra \\ ${ }^{1}$ Department of Sport Science Cenderawasih of University, Jayapura, Papua Indonesia
}

\begin{tabular}{l} 
Article Info \\
\hline Article History: \\
Submitted July 2020 \\
Accepted August 2020 \\
Published November 2020 \\
\hline Keywords: \\
Covid-19, petanque, \\
elite athlete \\
\hline DOI \\
https://doi.org/10.15294/ \\
kemas.v16i2.25444
\end{tabular}

\begin{abstract}
This research is a new paradigm mix method by combining grounded theory and case study construction, which involved 11 elite Papuan petanque athletes, data taken from March to May 2020. Data instruments using physical test data, observations, questionnaires, documents, and interviews . Data analysis combines two elements, namely: qualitative, and quantitative. Then the results and discussion in this study are: (1) The health quality of athletes experiencing problems, this is marked by an increase in the proportion of body weight; (2) The physical quality of the athlete experienced a decrease in physical quality before the occurrence of a pandemic above $81.80 \%$ and dropped to below $72.70 \%$; (3) Psychologically, when viewed from the aspect of motivation (institutions and extrinsic), it is categorized as high during the pandemic. This research empirically provides a description of the impact received as a result of the Covid-19 outbreak in sports achievements. Steps that can be taken, namely coaching and competition must continue to run based on applicable health protocols and the importance of maintaining health and physical activity for elite athletes.
\end{abstract}

\section{Intoduction}

Clean and healthy air becomes the main estuary of the pulse of human life (Rochman, Nasrudin, Muslim, \& Hermita, 2017), because with these prerequisites humans can have a prime and healthy life. Health is the degree to which humans are able to carry out activities without disease disorders, and perform stable mental states (Purcell, Gwyther, \& Rice, 2019). The productivity of active human performance is strongly influenced by three main elements of health: (1) Physical, where humans can work optimally without feeling tired (Najib, Nisa, Nugroho, Widowati, \& Yang, 2020); (2) Mental, when someone produces the best work with full awareness (Parnabas, Parnabas, \& Parnabas, 2015); and (3) Spiritual, namely the vertical relationship between creator and creature, and horizontal between all creatures of the universe (Hanani, 2017). The three combinations are then implemented in sports into the spirit of hard work, smart work, and sincere work. The whole series of work and human health on earth today is very disturbed by the emergence of a pandemic disease phenomenon. Covid-19 or (corona virus diseseae) horrendous at the end of 2019, the total world of this virus has infected more than 300,000 people with the percentage of mortality reaching more than $30 \%$. The latest developments in Indonesia until June 7, 2020 the number of cases of Covid-19 reached 31,186 . In addition to the continuing increase in numbers, there is something more important that this virus outbreak has not yet been found as a vaccine drug, and has had a wide impact on all sectors of the world community interaction. The characteristics of Covid-19 are still mysterious, where the virus can infect people through transmission of nasal or mouth splashes from infected people (Buana, 
2020). Objects around humans that have been exposed to Covid-19 radiation can then be a conduit of this virus and then be transmitted to people who touch it or are in the reach of the radius through the air gusts. Then people affected by this virus experience high fever, cough symptoms, influenza-like colds, sore throat and diarrhea (Hanoatubun, 2020). The active incubation period in the human body is approximately 14 days, and this virus is able to survive freely in the air for 3 hours before dying by itself (Pakpahan, 2020).

The impact of co-19 with social distancing also hit the elite of Papuan petanque athletes in welcoming the 2020 National Sports Week (PON) which was later postponed in 2021. Medal productivity as a means of achievement is greatly supported by maximum physical, mental, technical and tactical performance (Widowati, 2015). Some of the objectives in the organization of PON include: (1) As a manifestation of the unity of nationalism, within one country of Indonesia; (2) Equitable development, Indonesia is a unique country separated by inter-land seas in various islands with ethnic, cultural and religious diversity; (3) Participation as a global citizen who preserves sports value, medical devices and achievements, this is in accordance with its motto: "sport for all"; and (4) Reflections on entertainment, performing arts, and economic turnaround, where it is said that the success of the PON is the success of the match and the success of the host is a socioeconomic success.

Speaking of PON is the contingent of Papua as the host also did not escape the impact obtained. There are 1000 more Papuan athletes stagnated due to disruption of the registered training program. When dissected more deeply, the Papuan petanque sport (Cabor) is greatly affected by the limited access. After getting a fresh breath of hope that petanque as a sport that is starting to rise is finally allowed to compete in the competition as a series of PON outside Papua, but the bitter pill must be accepted when the reality that occurs at this time is an extraordinary event due to Covid-19. Petanque is one of the relatively new sports in Indonesia and especially Papua, this sport began to emerge and was popular in the late 2016's. At first petanque was introduced in a limited circle within the scope of students and lecturers at the Faculty of Sports Science (FIK) at Cenderawasih University (Uncen). Furthermore, with the support of Uncen and KONI (Indonesian National Sports Committee) Papua Province Petanque developed into an increasingly well-known sport in Papua. This development has led to the formation of elite Papuan Petanque elite contingents. Towards the XX PON event in Papua, all preparations and programs have been carried out and arranged carefully. The research that has been carried out has the main objectives of: (1) Assessing the athlete's health status; (2) Assess the physical impact of the implementation of social distancing and the complexity of the athlete's programmed routine programmed movement activities; (3) Assessing athlete achievement motivation in pandemic situations; and (4) Providing data on the fact that economic, social and cultural impacts and policies have taken place. In depth, this study then provides a picture of the chaotic graphs of the combined stages of the training program that has been carried out for years. The value of the benefits of this scientific study is to provide a form of community awareness to be aware and have a human sensitivity to the disaster that occurred, then to provide an educational message for the community to submit to, discipline, and obey the rules of health and build empathy among humans.

\section{Method}

The research that has been carried out is a new paradigm in mix method, namely: First, referring to the steps of grounded theory (Khan, 2014), to uncover a phenomenal new fact; Second, patterned case study construction, in exploring the problems that occur; Third, descriptive qualitative-quantitative $(\mathrm{Hu} \&$ Chang, 2017), in providing justification for the relationship of values and answers to research problems. This research was conducted in the scope of the Papua petanque sports community, with a distribution of subjects as many as 11 elite athletes. The implementation time is between March and May 2020. The research subjects were chosen based on several key criteria, namely: First, the top athletes who have high skill and ability to compete; Secondly, petanque sports have a high level of concentration and 
physicality which must also be good; Third, this sport has become a sports icon driven by universities that can produce potential athletes as a provision of skills other than academic; Fourth, the emergence of petanque was initially considered a low class sport, so that through research related to petanque had an impact on people's views and stigma towards more massive specialization.

This study uses two main instruments: First, the main instrument is sourced from key informants and additional informants in the form of field notes, online interview observations of athletes and coaches, training performance documents and championship results at the end of 2019, photos or video of activities practice and competition; Second, supporting instruments namely questionnaire, data on physical strength results and periodic techniques at the end of 2019, as well as physical and technical testing data independently performed on each athlete's personal (Pelana, Irfansyah, \& Setiakarnawijaya, 2019). The activities of this research data collection are as follows: First, in-depth observations and interviews related to the whole series of activities of elite Papuan athletes in preparation for the PON; Second, convert the physical test results at the end of the 2019 training period in the form of data description research sentences; Third, simultaneous physical, technical, and motivation testing of personal participation in data collection in the field; Fourth, triangulation of research data. This research uses the Cresswell method in justifying data analysis, with component patterns used, namely: First, cluster collection, and Second, direct case interpretation.

\section{Results and Discussion}

The results of measuring the athlete's nutritional status reflect the level of health experienced, these are as shown in Table 1.

The data in Table 1 shows that between January and May 2020 there was a weight gain of 0,8 to $2 \mathrm{~kg}$. Common obstacles faced by athletes regarding athlete health are related to: (1) Athletes spend more time at home, so routine training is reduced; (2) The pattern of food consumption as an athlete's nutritional intake is out of control, especially because of financial conditions and then looking for inexpensive supplementary foods that are not necessarily guaranteed to be clean and high in fat; (3) Athletes divert boredom by playing smartphones with a lot of digital play, this situation also increases the risk of weight gain; and (4) The resting pattern of the athlete becomes irregular, because more are staying at home and the training activities carried out are independent. Based onall the descriptions above, it can be concluded that the implementation of many activities carried out by athletes from

Table 1. Nutritional Status Data in December 2019 and Mei 2020

\begin{tabular}{lllllllll}
\hline \multicolumn{7}{l}{ December 2019 } & \multicolumn{7}{l}{ Mei 2020 } \\
\hline Weight & Height & Index & Category & Weight & Height & Index & Category & Chart \\
\hline 54 & 172 & 18,25 & Thin & 56 & 172 & 18,93 & Normal & +2 \\
76,4 & 180,6 & 23,42 & Normal & 78,4 & 180,6 & 24,04 & Normal & +2 \\
50,4 & 159,3 & 19,86 & Normal & 51,2 & 159,3 & 20,18 & Normal & $+0,8$ \\
78 & 175,7 & 25,27 & Fat & 79,2 & 175,7 & 25,66 & Fat & $+1,2$ \\
57 & 162,6 & 21,56 & Normal & 58 & 162,6 & 21,94 & Normal & +1 \\
51 & 167 & 18,29 & Thin & 52 & 167 & 18,65 & Normal & $+1,6$ \\
50,4 & 151,6 & 21,93 & Normal & 51,5 & 151,6 & 22,41 & Normal & $+1,1$ \\
41,3 & 151,5 & 17,99 & Thin & 42,5 & 151,5 & 18,52 & Normal & $+1,2$ \\
50,4 & 150,5 & 22,25 & Normal & 51,3 & 150,5 & 22,65 & Fat & $+0,9$ \\
67 & 162 & 25,53 & Fat & 68,3 & 162 & 26,02 & Fat & $+1,3$ \\
45 & 150,6 & 19,84 & Normal & 46,1 & 150,6 & 20,33 & Normal & $+1,1$ \\
\hline
\end{tabular}

Source: Primary Data, 2020 
residential homes as a result of the Covid-19 pandemic makes athletes experience irregular patterns of physical activity, rest, and especially food intake consumed. The most extreme effect of this situation is the reduction in productivity and disruption of achievement targets. Physical endurance is part of the performance picture of the athlete; the data in Table 2.

Based on the data in Table 2 can be seen how the athlete graph figures, there is 1 person who has increased. However, the majority of athletes experienced a decrease in physical quality of as many as 10 people, this can be seen from the $\mathrm{Vo}^{2} \mathrm{Max}$ test results. As a percentage of the performance figures, in December 2019 athletes who fall into the above category are sufficient to reach $81,80 \%$. Then based on athlete performance data in May 2020, the percentage above the adequate category is $72,70 \%$. How this phenomenon occurs, researchers then deepen the case by conducting interviews with athletes. Implicitly, the current event is both an extraordinary event and a rare moment. Plague has changed all aspects of life including athletes. The conclusion from the description of the physical quality is that with the amount of time the athlete is at home, then with the limited time spent training so that the impact on the percentage decrease in $\mathrm{Vo}^{2} \mathrm{Max}$.

This questionnaire on motivation is used to measure the extent of motivation of Papuan petanque elite athletes. The results of calculating the intrinsic dimension motivational answer questionnaire scores can be explained as below: (1) Indicator of desire: there are as many as 5 questions, while the results of the calculation of the score are a total score of 551, a maximum score of 700, a percentage score of $78.85 \%$. Based on these results it can be said that the motivation of athletes to get a medal measured on the indicator of desire can be categorized high; (2) Indicators of need: there are as many as 3 questions, while the results of the calculation of the score are a total score of 361 , a maximum score of 420 , a percentage score of $85.71 \%$. Based on these results it can be said that the motivation of athletes to get an award measured in needs indicators can be categorized very high; (3) Aspiration factors: there are as many as 4 questions, while the results of the calculation of the score are a total score of 418 , a maximum score of 560, a percentage score of $74.83 \%$. Based on these results it can be said that the motivation of athletes in getting decent work is measured in indicators of goals can be categorized high; (4) Talent indicator: there are 3 questions, while the score calculation results are total score of 337, maximum score of 420 , percentage score of $80.05 \%$. Based on these results it can be said that the motivation of athletes in choosing petanque measured on the talent indicator can be categorized very high;

Table 2. Physical Resistance Data in December 2019 and Mei 2020

\begin{tabular}{|c|c|c|c|c|c|c|c|c|}
\hline \multicolumn{4}{|c|}{ December 2019} & \multicolumn{4}{|c|}{ Mei 2020} & \multirow{2}{*}{$\begin{array}{l}\text { Chart } \\
\text { (Vo2Max) }\end{array}$} \\
\hline Level & Shuttle & Vo2Max & Category & Level & Shuttle & Vo2Max & Categoriy & \\
\hline 5 & 5 & 31,4 & Poor & 6 & 5 & 34,8 & Average & $+3,4$ \\
\hline 6 & 8 & 35,8 & Average & 6 & 1 & 33,3 & Average & $-2,5$ \\
\hline 7 & 4 & 37,8 & Good & 7 & 3 & 37,5 & Good & $-0,3$ \\
\hline 6 & 1 & 33,3 & Average & 5 & 3 & 30,6 & Poor & $-2,7$ \\
\hline 7 & 1 & 36,8 & Good & 6 & 2 & 33,7 & Average & $-3,1$ \\
\hline 9 & 10 & 46,5 & Excellent & 7 & 9 & 39,5 & Good & -7 \\
\hline 5 & 2 & 30,3 & Poor & 5 & 1 & 29,9 & Poor & $-0,4$ \\
\hline 7 & 8 & 39,2 & Good & 7 & 2 & 37,1 & Baik & $-2,1$ \\
\hline 5 & 8 & 32,5 & Average & 5 & 7 & 32,1 & Average & $-0,4$ \\
\hline 6 & 1 & 33,3 & Average & 5 & 3 & 30,6 & Poor & $-2,7$ \\
\hline 7 & 1 & 36,8 & Good & 6 & 5 & 34,8 & Average & -2 \\
\hline
\end{tabular}

Source: Primary Data, 2020 
and (5) Feeling indicator: there are as many as 2 questions, while the results of the calculation of the score are total score of 234, maximum score of 280 , percentage score of $83.22 \%$. Based on these results it can be said that the motivation of athletes to practice in a pandemic period measured in indicators of feeling can be categorized very high; (6) Overall indicators: the total score of the intrinsic dimension questionnaire answers overall indicator of 1350 , the maximum score of 2380 , the percentage score of $79.84 \%$.

The results of calculating the extrinsic dimension motivation questionnaire answers can be explained as follows: (1) Indicators of family factors: there are as many as 4 questions, while the results of the calculation of the score are a total score of 415 , a maximum score of 560 , a percentage score of $73.94 \%$. Based on these results it can be said that the motivation of athletes in achievement is measured in indicators of family factors can be categorized high; (2) Indicators of the training environment: there are 6 questions, while the results of the calculation of the score are the total score of 630 , the maximum score of 840 , the percentage score of $75.11 \%$. Based on these results it can be said that the motivation of athletes in achievement is measured in indicators of the training environment can be categorized high; (3) Educational environment factors: there were as many as 5 questions, while the results of the calculation of the score were a total score of 610, a maximum score of 700 , a percentage score of $87.05 \%$. Based on these results it can be said that the motivation of athletes in achievement measured in indicators of the learning environment can be categorized high; and (4) Overall indicators: the total score of the extrinsic dimension questionnaire answers to the overall indicator is 1665 , the maximum score is 2100 , the percentage score is $78.76 \%$. Based on these results it can be said that motivation in the extrinsic dimension can be categorized high.

First, the results of the evaluation showed that during the 3-month period of social distancing, the average athlete's body weight graph increased by 0.8 to $2 \mathrm{~kg}$. Some potential causes are: (1) The pattern of consumption of high saturated fat foods with irregular duration of time; (2) reduced training intensity; and (3) overload resting rhythm. Papuan petanque athletes from a strict regimens to an uncontrolled diet with a composition that is high in fat and low in fiber, causes an imbalance in nutritional intake and is a risk factor that contributes greatly to the emergence of various health problems namely: obesity, hypertension, dyslipidemia, and insulin resistance, known as metabolic syndrome. Fat has an important role for the body. Apart from being an energy source, fat is needed by the body as a fat soluble vitamin solvent, a component of cell membranes as a hormone, immune system, and thermoregulator (Budiono, I., 2013). However, if consumed in excessive amounts it will be dangerous because it builds up on blood vessels and causes atherosclerosis and blockages in blood vessels (Kang, Yang, \& Xiao, 2020). The application of a balanced menu pattern by reducing the consumption of foods containing saturated fats and high cholesterol, and increasing the consumption of foods containing unsaturated fats such as fish, fish oil, vegetable oil, and nuts. Adequate and balanced fat intake between saturated, unsaturated, cholesterol and other fats will be able to fulfill the above functions. Suggested fat intake is not expected to exceed $25 \%$ of the total energy consumed a day, maximum saturated fat is $10 \%$ of total energy, and unsaturated fat ranges from 3 to $7 \%$ of total energy.

Second, empirical data of the $\mathrm{Vo}^{2} \mathrm{Max}$ test results using the MFT test instrument (multi fitness test) shows that if the percentage of the performance index, in December 2019 athletes included in the above category is enough $81.80 \%$, then in the athlete performance data in May 2020, the percentage in Top category is $72.70 \%$ enough. This means there is a decrease in the index percentage of $7.30 \%$ in the span of 3 months. The average graph decrease in the value of Vo2Max is -0.3 to -7 . The average decline in the performance index is an accumulation of 10 elite athletes, but there is an interesting phenomenon where there is 1 athlete who actually experienced an increase in the ability of $\mathrm{Vo}^{2} \mathrm{Max}$. After deepening the case, it was found that 10 athletes who experienced a decrease in the physical performance index were caused by: (1) weight gain as a result of 
changing dietary patterns; (2) Discipline and reduced duration of exercise, while 1 person who experienced an increase in physical performance index is caused by: (1) Being able to maintain eating and resting patterns; and (2) motivation and discipline of the exercise. The research results obtained are related to several other studies, as below: (1) Physical activity and lifestyle of athletes every day have an impact on the physical performance of athletes; (2) There is a significant relationship between physical condition and the achievements of the West Java PON XIX martial arts athlete with a score of 0.494 (Yusup, Erawan, \& Hermanu, 2017); and (3) Covid-19 pandemic for Japanese coaches and athletes and paralympic games has an impact on the cancellation of training schedules and postponement of the match, this has resulted in a decrease in physical performance, and added fear will contract Covid-19 (Taku \& Arai, 2020). Excellent physical performance can support other aspects such as technique, tactics and mentality (Latorre-Román, GarcíaPinillos, \& Mora-López, 2020). Good physical performance is very decisive in supporting the athlete's task in the match so that he can perform optimally. The physical condition training program must be well planned and systematic and aimed at improving the physical fitness and functional abilities of the body system so as to enable athletes to achieve better performance.

Third, the research results obtained can be explained as below: (1) The intrinsic motivation dimension consists of 5 indicators, namely: desires, feelings, needs, ideals, and talents. The results of the overall value of the indicator of 1350, the maximum score of 2380 , the percentage score of $79.84 \%$, and means that the results can be said that motivation on the intrinsic dimension is included in the high category; and (2) The dimensions of extrinsic motivation consist of 3 indicators (family factors, the environment of the training ground, and the educational environment. The overall score of the indicator is 1665 , the maximum score is 2100 , the percentage score is $78.76 \%$, and means that the results can be said that motivation on the extrinsic dimension including the high category. There are several research results that provide reinforcement related to motivation and sports achievement, among others: (1) There is a positive and significant relationship between motivation and the achievements of soccer athletes (Apriansyah, Sulaiman, \& Mukarromah, 2017); and (2) Achievement for athletes who come from students majoring in sports has a higher level of correlation (Beckford, Poudevigne, Irving, \& Golden, 2011), when compared to athletes with educational backgrounds outside of sports majors (Akyol \& İmamoğlu, 2019). Psychological factors are very important in achievement sports such as petanque especially during matches, motivation is certainly very influential on the results to be achieved. McClelland stressed the importance of the need for achievement, because people who succeed in business and industry are people who have accomplished everything.

\section{Conclusion}

This research has three main subjects as outlined in the results and discussion chapter, while the conclusions are as follows: (1) The quality of athlete's health experiences constraints due to limited physical activity, over a period of 3 months the implementation of social distancing the average athlete's body weight graph has increased 0.8 to $2 \mathrm{Kg}$; (2) In terms of physical quality, look at the percentage of the performance index the average athlete was above $81.80 \%$, then in the athlete performance data of physical performance of the athlete above the sufficient category was $72.70 \%$; and (3) Psychologically when viewed from the aspect of motivation is still in good condition, based on intrinsic and extrinsic dimension data which are included in the high category. Recommendations that can be given from the results of this research study are: (1) Trainers and athletes to form new normalcy in making training programs both in the pandemic and post-pandemic periods; (2) Stakeholders can design future sports facilities and infrastructure that are safe with standard health protocol standards; (3) To the public at large, discipline must comply with rules set by the government relating to the prevention and treatment of epidemics or dangerous infectious diseases.

\section{References}

Akyol, P., \& İmamoğlu, O., 2019. The Relationship between Motivation and Flow States in Sports Faculty Students. Asian Journal of Education 
and Training, 5(3),pp.440-446,.

Apriansyah, B., Sulaiman., \& Mukarromah, S., 2017. Kontribusi Motivasi, Kerjasama, Kepercayaan Diri terhadap Prestasi Atlet Sekolah Sepakbola Pati Training Center di Kabupaten Pati. Journal of Physical Education and Sports, 6(2),pp.101-107.

Beckford, T., Poudevigne, M., Irving, R., \& Golden, K., 2011. Mental Toughness and Coping Skills in Male. Journal of Human Sport and Exercise, 11(3),pp.338-347.

Buana, D.R., 2020. Analisis Perilaku Masyarakat Indonesia dalam Menghadapi Pandemi Virus Corona (Covid-19) dan Kiat Menjaga Kesejahteraan Jiwa. SALAM: Jurnal Sosial Budaya Syar-I, 7(3),pp.217-226.

Budiono, I., 2013. Pengembangan Model Indeks Pembangunan Gizi. Jurnal Kesehatan Masyarakat, 8(2),pp.166-175.

Hanani, E., 2017. The Study on Value of Recreational Sports Activity of Urban Communities. Jurnal kesehatan Masyarakat, 12(2),pp.96101.

Hanoatubun, S., 2020. Dampak Covid -19 Terhadap Prekonomian Indonesia. EduPsyCouns: Journal of Education, Psychology and Counseling, 2(1),pp.146-153.

Hu, C., \& Chang, Y., 2017. John W. Creswell, Research Design: Qualitative, Quantitative, and Mixed Methods Approaches. Journal of Social and Administrative Sciences, 4(2),pp.205-207.

Kang, Z., Yang, Y., \& Xiao, B., 2020. Dietary Saturated Fat Intake and Risk of Stroke: Systematic Review and Dose-Response Meta-Analysis of Prospective Cohort Studies. Nutrition, Metabolism and Cardiovascular Diseases, 30(2),pp.179-189.

Khan, S.N., 2014. Qualitative Research Method: Grounded Theory. International Journal of Business and Management, 9(11),pp.224-233.

Latorre-Román, P., García-Pinillos, F., \& MoraLópez, D., 2020. Jump-Rope Training: Improved 3-km Time-Trial Performance in Endurance Runners via Enhanced LowerLimb Reactivity and Foot-Arch Stiffness. International Journal of Sports Physiology and Performance, 15(7),pp.927-933.

Najib, Nisa, A., Nugroho, E., Widowati, E., \& Yang,
C., 2020. Developing Reproductive Health Communication in Early Marriage. Jurnal Kesehatan Masyarakat, 15(3),pp.441-449.

Pakpahan, A.K., 2020. Covid-19 dan Implikasi Bagi Usaha Mikro, Kecil, dan Menengah. Jurnal Ilmiah Hubungan Internasional, Special Edition,pp.59-64.

Parnabas, V., Parnabas, J., \& Parnabas, A., 2015. The Influence of Mental Imagery Techniques on Sport Performance Among Taekwondo Athletes. European Academic Research, II(11),pp.14729-14734.

Pelana, R., Irfansyah, R., \& Setiakarnawijaya, Y., 2019. Study of Correlation Between Power of The Arm Muscle and Rom (Range of Motion) of Shoulder With The Results of 9 Meters Distance Shooting in Petanque Athlete Faculty of Sport Science State University of Jakarta, Indonesia. European Journal of Physical Education and Sport Science, 5(9),pp.8-18.

Purcell, R., Gwyther, K., \& Rice, S., 2019. Mental Health In Elite Athletes: Increased Awareness Requires An Early Intervention Framework to Respond to Athlete Needs. Sport MedicineOpen, 5(46),pp.1-8.

Rochman, C., Nasrudin, D., Muslim, M., \& Hermita, N., 2017. Characteristics of The Ability of Physics Concept in Enrichment Teaching Materials of Natural and Mineral Resources (NMRs) Literacy. Jurnal Pendidikan IPA Indonesia, 6(2),pp.252-256.

Taku, K., \& Arai, H., 2020. Impact of COVID-19 on Athletes and Coaches, and Their Values in Japan: Repercussions of Postponing the Tokyo 2020 Olympic and Paralympic Games. Journal of Loss and Trauma, 25(5),pp.1-8.

Widowati, A., 2015. Modal Sosial Budaya dan Kondisi Lingkungan Sehat dalam Pembinaan Prestasi Olahraga Pelajar. Jurnal Kesehatan Masyarakat, 10(2),pp.218-226.

Yusup, U., Erawan, B., \& Hermanu, E., 2017. Hubungan Kondisi Fisik, Tingkat Kesehatan, Psikologis dengan Prestasi Atlet Cabang Olahraga Beladiri Jawa Barat di PON XIX 2016. Jurnal Kepelatihan Olahraga, 10(2),pp.74-84. 